九州大学学術情報リポジトリ

Kyushu University Institutional Repository

\title{
Assessing Water Quality in the Cai River, Ninh Thuan Province, Vietnam, by Field Observations
}

NGOC, Trieu Anh

Thuy loi University

THU, Vu Thi Hoai

Thuyloi University

HIRAMATSU, Kazuaki

Faculty of Agriculture, Kyushu University

THAI, Vu Le Duy

Thuy loi University

他

https://doi.org/10.5109/4103897

出版情報 : 九州大学大学院農学研究院紀要. 65 (2)，pp.321-330，2020-09. Faculty of Agriculture， Kyushu University

バージョン :

権利関係 : 


\title{
Assessing Water Quality in the Cai River, Ninh Thuan Province, Vietnam, by Field Observations
}

\section{Trieu Anh NGOC ${ }^{1, *}$, Vu Thi Hoai THU ${ }^{1}$, Kazuaki HIRAMATSU, Vu Le Duy THAI ${ }^{1}$, Do Van DAO ${ }^{1}$, Vu Hai SON ${ }^{1}$ and Pham Tran Hoang SON ${ }^{1}$}

\author{
Laboratory of Water Environment Engineering, \\ Division of Bioproduction Environmental Sciences, \\ Department of Agro-environmental Sciences, Faculty of Agriculture, \\ Kyushu University, Fukuoka 819-0395, Japan \\ (Received May 15, 2020 and accepted May 27, 2020)
}

\begin{abstract}
The Cai River is the main river in Ninh Thuan Province, Vietnam, and plays a crucial role as arterial river in the entire province. The Cai River is the main river of the Cai River basin; the Sat, Cho Mo, and Ngang Rivers are located on the left hand side, whereas the Ong, Cha, Than, Quao, and Lu Rivers are located on the right hand side of the basin. In this study, the prevailing water quality of the Cai River basin was evaluated by comparing the observed water quality in the Cai River and at the confluences of its tributaries, and the evaluated water quality of the Cai River was compared with the Vietnamese standards. Several parameters, including the $\mathrm{pH}$, total suspended solids, phosphate, dissolved oxygen, biochemical oxygen demand, and chemical oxygen demand were selected for evaluation. Results show that in comparison with water quality standards of Vietnam for irrigation or other domains with low water quality, the water quality standards in the Cai River and in confluences of its tributaries were not significantly affected by polluting factors.
\end{abstract}

Key words: Cai River basin, confluence, tributaries, water quality standard of Vietnam

\section{INTRODUCTION}

The Cai River basin located in Ninh Thuan Province, originates in Khanh Son District, Khanh Hoa Province, and terminates in Dong Hai Ward, Phan Rang-Thap Cham City, Ninh Thuan Province. Its length is about $120 \mathrm{~km}$ with a basin area of approximately $2050 \mathrm{~km}^{2}$. The main rivers of the Cai River basin are shown in Fig. 1., showing the Cai River as the main river; the Sat, Cho Mo, and Ngang Rivers on the left-hand side, whereas the

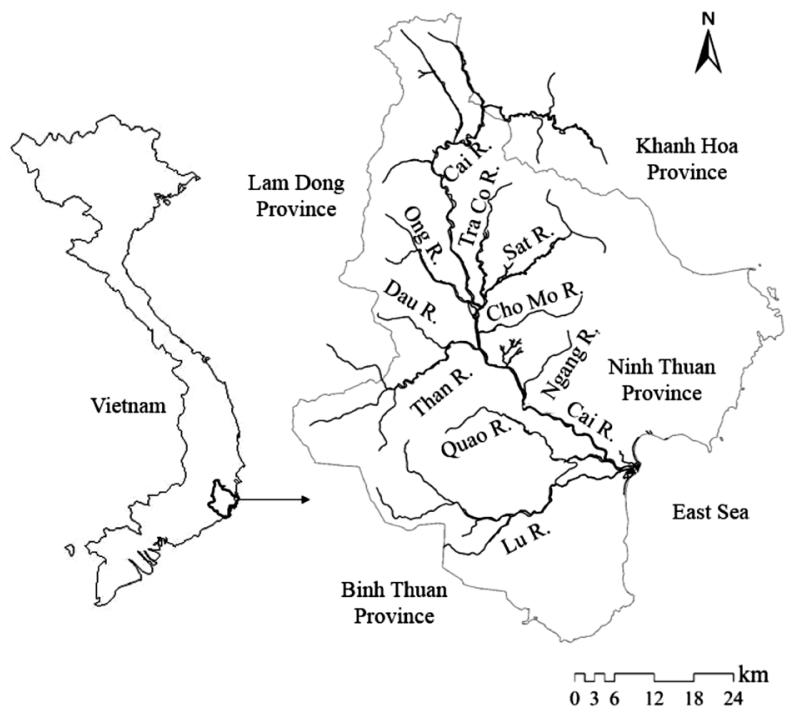

Fig. 1. Location of the Cai River basin and its main rivers

1 Thuyloi University, 175 Tay Son, Dong Da, Ha Noi City, Vietnam

* Corresponding author (E-mail: ngocta@tlu.edu.vn)
Ong, Cha, Than, Quao, and Lu Rivers on the right-hand side.

The Ninh Thuan Province has the highest temperature and lowest precipitation in Vietnam with frequent drought and water shortages; therefore, the Cai River plays a vital role as the arterial river. The Cai River supplies water for irrigation, serves economic activities and tourism, and regulates the flow and drain of floods. It is the main source of water supply for over $80 \%$ of the water demand in Ninh Thuan Province for multiple purposes. Therefore, water reserves are an essential factor affecting water availability, and water quality is also a significant factor directly affecting the water sector.

Results show that water quality of the Cai River basin was stable from 2012 to 2014, and met the permitted standards of the national technical regulation on surface water quality of the Ministry of Natural Resources and Environment (QCVN 08-MT:2008/BTNMT) (MONRE, 2008). However, the concentration of organic matter and nutrient contamination increased significantly, exceeding the sanctioned standard by 2015, especially in the northern canals in Phan Rang and Ninh Hai branches (Department of Natural Resources and Environment of Ninh Thuan Province, 2018). Water quality at some locations showed signs of organic pollution, indicated by the chemical oxygen demand (COD) and biochemical oxygen demand $\left(\mathrm{BOD}_{5}\right)$. The dissolved oxygen (DO) in the surface water of the northern branch of Phan Rang was low in 2011 and 2012. Although BOD did not exceed the standard, it increased over the years. Several monitoring locations in the northern channel of the Phan Rang and Ninh Hai branches have recorded $\mathrm{BOD}_{5}$ violating QCVN 08-MT:2008/BTNMT standard. The pollution resulted from the Cai River and its north- 
ern and southern canals receiving wastewater from industrial, agricultural, and domestic activities. Currently, only Phan Rang-Thap Cham city has one centralized local wastewater treatment plant with a capacity of $5000 \mathrm{~m}^{3} / \mathrm{d}$, whereas there are none in the districts in Ninh Thuan Province (Department of Natural Resources and Environment of Ninh Thuan Province, 2018).

According to Meybeck et al. (1996), water quality demonstrates the suitability of water sources to maintain physicochemical and biochemical processes occurring within and serve different uses. It can be determined by a series of different parameters determining the intended use of each water source and depends on the physicochemical and biological parameters of water. These parameters depend on natural factors (such as geology, topography, meteorology, hydrology, and biology) of the river basin and fluctuate seasonally depending on the flow conditions such as flow, weather, and water-levels. In addition, human intervention has a significant influence on water quality: changes in hydrological flows (dam construction and drainage, among others), discharging pollutants, including domestic, industrial, and urban sewage, and spreading chemicals on agricultural land in the river basin hamper the water quality. According to Cooke et al. (2000), there are two ways to assess surface water quality: concentration (mg/L) and load (ton/year).

Water quality parameters are expressed through three indicators: physical criteria $(\mathrm{pH}$, temperature, color, turbidity, and total suspended solids); chemical indicators (total alkalinity, degree of hardness, DO, $\mathrm{BOD}_{5}$, COD, nitrogen compounds, and phosphorus compounds); and biological criteria (bacteria, viruses, and other aquatic microorganisms) (Ton 2007; Le 2008; Pham et al. 2011). To assess the water quality in rivers, canals, and ponds, scientists often rely on their water quality parameters and not on limitations specified in national standards.

The Cai River basin has a complex network of 32 water quality monitoring stations (Department of Natural Resources and Environment of Ninh Thuan Province, 2018). However, these stations are unevenly distributed, concentrated mainly in the downstream, industrial, and densely populated areas. The number of stations along the main river of the Cai River is small and sparse. In addition, for the tributaries at the main flow, most of the monitoring data do not ensure the specificity and continuity in analyzing and evaluating prevailing situations and the changes in surface water quality in the Cai River basin. To assess the water quality of the Cai River basin, in addition to acquiring data of the monitoring network, it is necessary to conduct monitoring at some point on the main river of the Cai River and its tributaries (MONRE, 2009).

Herein, the prevailing water quality of the Cai River basin was evaluated by investigating the observed water quality in the Cai River and the confluences of its tributaries. In addition, surface water quality was assessed over time and space by determining the changing trend of water quality and comparing it with the latest techni- cal regulations on surface water quality of the Ministry of Natural Resources and Environment QCVN 08-MT:2015/ BTNMT (MONRE, 2015). For the monitoring points at the confluence of the Cai River and its tributaries, the temperature, $\mathrm{pH}, \mathrm{DO}, \mathrm{COD}$, phosphate $\left(\mathrm{P}_{-} \mathrm{PO}_{4}\right), \mathrm{BOD}_{5}$, and total suspended solids (TSS) were considered for the evaluation.

\section{MATERIALS AND METHODS}

\section{Methodology}

On the main river of the Cai River, seven additional measurement points were arranged at the points of confluence of its tributaries. The specific locations of the monitoring points are summarized in Table 1 and Fig. 2. With a frequency of 10 samples for each monitoring position, the proposed monitoring sites ensured a reasonable and uniform distribution between locations and provided objectivity and accuracy in analyzing and assessing the water quality of the Cai River basin. There are seven tributaries of the Cai River basin, i.e., the tributaries of the Ong, Tra Co, Sat, Dau, Mo, and Ngang Rivers, with a total length of over $200 \mathrm{~km}$, and most of these do not have any monitoring stations or specific data on water quality. In addition, there are many reservoirs, hydroelectric dams, and domestic surface water exploitation projects, which have a significant influence on the water quality of the tributaries.

To evaluate the water quality of the Cai River, sampling and monitoring at 14 points, including urban and densely populated areas, and socio-economic development activities, are shown in Table 2 and Fig. 3.

Field observations were conducted in the dry season of April 2019. For the monitoring points, temperature,

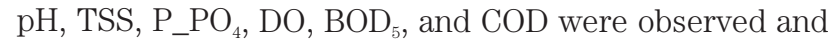
analyzed.

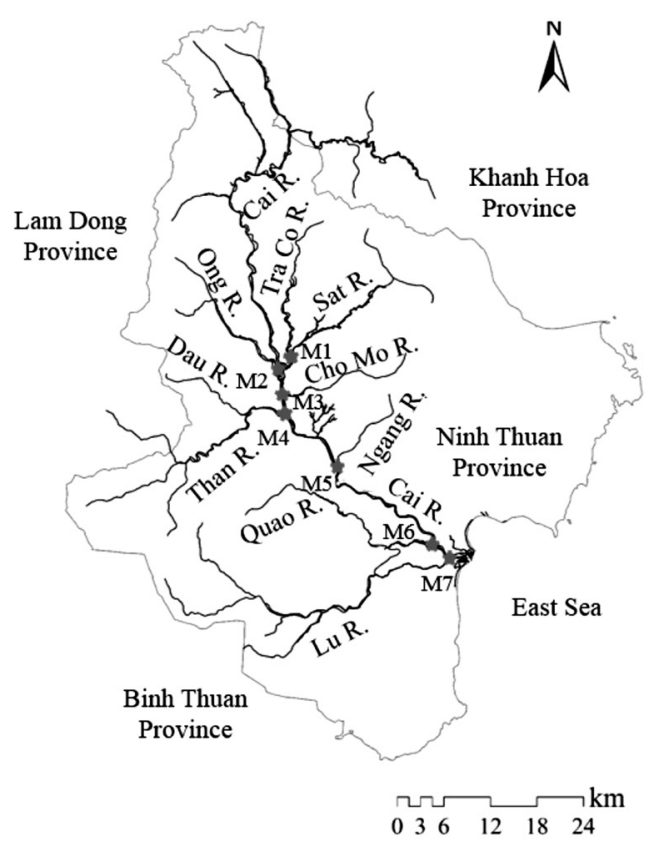

Fig. 2. Location map of seven points of confluence of tributaries flowing into the main river. 
Table 1. Location of seven points of confluence of tributaries flowing into the main river

\begin{tabular}{|c|c|c|c|c|c|c|c|}
\hline No. & Location & Symbol & $\begin{array}{l}\text { Longitude } \\
\left(^{\circ}\right)\end{array}$ & $\begin{array}{l}\text { Latitude } \\
\quad\left({ }^{\circ}\right)\end{array}$ & $\begin{array}{l}\text { Number of } \\
\text { samples }\end{array}$ & $\begin{array}{l}\text { Time for sampling } \\
\text { (2019) }\end{array}$ & Weather condition \\
\hline 1 & $\begin{array}{l}\text { The confluence of the Tra Co and } \\
\text { Sat Rivers with the Cai River }\end{array}$ & M1 & 108.8100 & 11.7630 & 10 & $\begin{array}{c}04 / 138 \mathrm{~h} 00 \\
-15 \mathrm{~h} 00\end{array}$ & Sunny and cloudless \\
\hline 2 & $\begin{array}{c}\text { The confluence of the Ong River } \\
\text { with the Cai River }\end{array}$ & $\mathrm{M} 2$ & 108.8090 & 11.7480 & 10 & $\begin{array}{l}04 / 148 \mathrm{~h} 00 \\
-15 \mathrm{~h} 00\end{array}$ & $\begin{array}{l}\text { Light sunny, less } \\
\text { cloudy, dry weather }\end{array}$ \\
\hline 3 & $\begin{array}{l}\text { The confluence of the Cho Mo River } \\
\text { with the Cai River }\end{array}$ & M3 & 108.8128 & 11.7308 & 10 & $\begin{array}{l}04 / 158 h 00 \\
-15 h 00\end{array}$ & Sunny and cloudless \\
\hline 4 & $\begin{array}{l}\text { The confluence of the Than River, } \\
\text { the Dau River with the Cai River }\end{array}$ & M4 & 108.8122 & 11.7083 & 10 & $\begin{array}{c}04 / 168 \mathrm{~h} 00 \\
-15 \mathrm{~h} 00\end{array}$ & $\begin{array}{l}\text { Light sunny, less } \\
\text { cloudy, dry weather }\end{array}$ \\
\hline 5 & $\begin{array}{c}\text { The confluence of the Ngang River } \\
\text { with the Cai River }\end{array}$ & M5 & 108.8496 & 11.6826 & 10 & $\begin{array}{l}04 / 178 \mathrm{~h} 00 \\
-15 \mathrm{~h} 00\end{array}$ & Sunny and cloudless \\
\hline 6 & $\begin{array}{l}\text { The confluence of the Quao River } \\
\text { with the Cai River }\end{array}$ & M6 & 108.9847 & 11.5539 & 10 & $\begin{array}{l}04 / 188 \mathrm{~h} 00 \\
-15 \mathrm{~h} 00\end{array}$ & Sunny and cloudless \\
\hline 7 & $\begin{array}{c}\text { The confluence of the Lu River with } \\
\text { the Cai River }\end{array}$ & M7 & 109.0050 & 11.5390 & 10 & $\begin{array}{c}04 / 198 \mathrm{~h} 00 \\
-15 \mathrm{~h} 00\end{array}$ & Sunny and cloudless \\
\hline
\end{tabular}

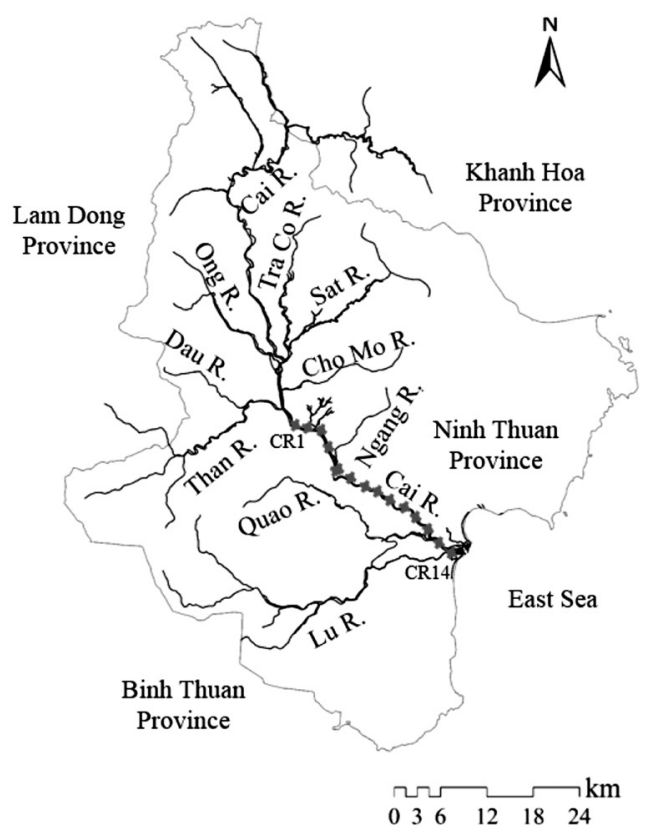

Fig. 3. Location for establishing monitoring points in the Cai River basin.
Samples were taken directly by winches with cranking at three vertical points in the same cross section: the left and right bank and middle of the river. After sampling at these three points, the samples were mixed for homogeneity, then put into a water sample container and stored, following regulations on the technical process of MONRE (2011).

After obtaining the analyzed data, the water quality results were compared with the national technical regulations on surface water quality of the Ministry of Natural Resources and Environment (QCVN 08MT:2015/BTNMT), as shown in Table 3. QCVN 08MT:2015/BTNMT is the Vietnamese standard for water quality parameters for irrigation or other domains with low water quality. It specifies the limitation of surface water quality parameters and helps evaluate and manage the quality of surface water as a basis for appropriate protection and use of water. It is also a basis for preparing and approving water use plans for determined purposes and assessing the suitability of surface water qual-

Table 2. Position coordinates of monitoring points in the Cai River basin

\begin{tabular}{cccccc}
\hline No. & Symbol & $\begin{array}{c}\text { Longitude } \\
\left({ }^{\circ}\right)\end{array}$ & $\begin{array}{c}\text { Latitude } \\
\left({ }^{\circ}\right)\end{array}$ & $\begin{array}{c}\text { Time for sampling } \\
(2019 / 04 / 25)\end{array}$ & Weather condition \\
\hline 1 & CR_1 & 108.8815 & 11.6278 & $7: 45$ & Light sunny, less cloudy, dry weather \\
2 & CR_2 & 108.8952 & 11.6179 & $8: 10$ & $\begin{array}{c}\text { Light sunny, less cloudy, dry weather } \\
3\end{array}$ \\
CR_3 & 108.9053 & 11.6171 & $8: 55$ & Sunny and cloudless \\
4 & CR_4 & 108.9143 & 11.6124 & $9: 15$ & Sunny and cloudless \\
5 & CR_5 & 108.9247 & 11.6089 & $10: 20$ & Sunny and cloudless \\
6 & CR_6 & 108.9395 & 11.6022 & $11: 10$ & Sunny and cloudless \\
7 & CR_7 & 108.9402 & 11.5967 & $12: 05$ & Sunny and cloudless \\
8 & CR_8 & 108.9418 & 11.5916 & $14: 00$ & Sunny and cloudless \\
9 & CR_9 & 108.9612 & 11.5894 & $14: 40$ & Sunny and cloudless \\
10 & CR_10 & 108.9702 & 11.5740 & $15: 15$ & Sunny and cloudless \\
11 & CR_11 & 108.9851 & 11.5627 & $15: 50$ & Sunny and cloudless \\
12 & CR_12 & 108.9844 & 11.5559 & $16: 10$ & Sunny and cloudless \\
13 & CR_13 & 108.9946 & 11.5527 & $16: 45$ & Light sunny, less cloudy, dry weather \\
14 & CR_14 & 108.9992 & 11.5443 & $17: 10$ & Light sunny, less cloudy, dry weather \\
\hline
\end{tabular}


Table 3. Limitation of some parameters of water quality based on QCVN 08-MT:2015/BTNMT (MONRE, 2015)

\begin{tabular}{ccccccc}
\hline & & \multicolumn{5}{c}{ Limitation } \\
\cline { 4 - 7 } No. & Parameters & Unit & \multicolumn{2}{c}{$\mathrm{a}$} & \multicolumn{2}{c}{$\mathrm{b}$} \\
\cline { 4 - 7 } & & & $\mathrm{a} 1$ & $\mathrm{a} 2$ & $\mathrm{~b} 1$ & $\mathrm{~b} 2$ \\
\hline 1 & $\mathrm{pH}$ & & $6.0-8.5$ & $6.0-8.5$ & $5.5-9.0$ & $5.5-9.0$ \\
2 & $\mathrm{DO}$ & $\mathrm{mg} / \mathrm{L}$ & $\geq 6.0$ & $\geq 5.0$ & $\geq 4.0$ & $\geq 2.0$ \\
3 & $\mathrm{BOD}_{5}$ & $\mathrm{mg} / \mathrm{L}$ & 4.0 & 6.0 & 15.0 & 25.0 \\
4 & $\mathrm{COD}_{n}$ & $\mathrm{mg} / \mathrm{L}$ & 10.0 & 15.0 & 30.0 & 50.0 \\
5 & $\mathrm{P}_{2} \mathrm{PO}_{4}$ & $\mathrm{mg} / \mathrm{L}$ & 0.1 & 0.2 & 0.3 & 0.5 \\
6 & $\mathrm{TSS}$ & $\mathrm{mg} / \mathrm{L}$ & 20.0 & 30.0 & 50.0 & 100.0 \\
\hline
\end{tabular}

ity for approved water use plans. Moreover, this regulation is the basis for controlling waste-sources discharged into receiving sources, ensuring that surface water sources are always suitable for use. Furthermore, it is the basis for implementing measures to improve and restore water quality.

\section{RESULTS AND DISCUSSIONS}

\section{Water quality at confluence points in the Cai River basin}

The results of the water quality analysis at the confluence points of the Cai River and its tributaries are summarized in Tables 4 to 10 and Figs. 4 to 9 .

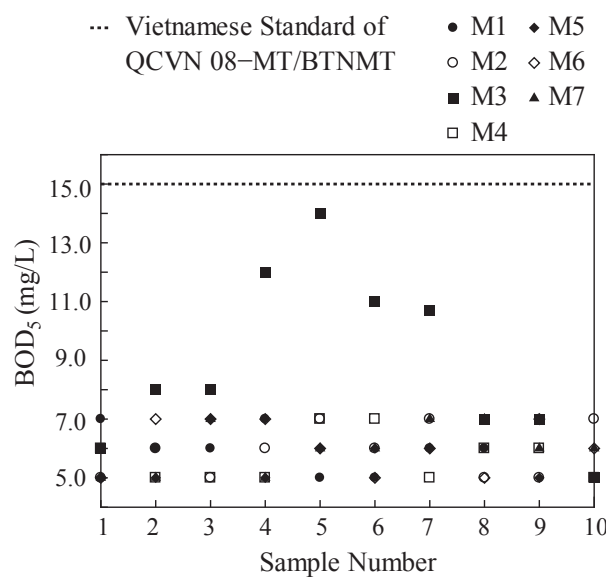

Fig. 6. $\mathrm{BOD}_{5}$ values at the seven confluences of tributaries and the Cai River.

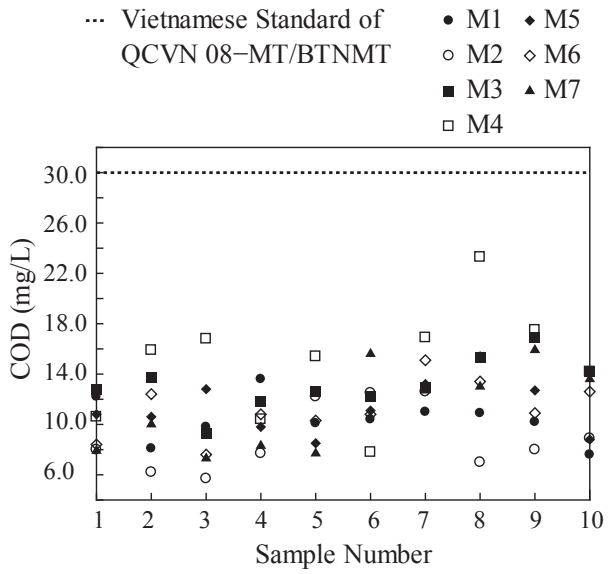

Fig. 7. COD values at the seven confluences of the tributaries and the Cai River. tributaries and the Cai River

- M3 $\triangle \mathrm{M} 7$

$\square$ M4

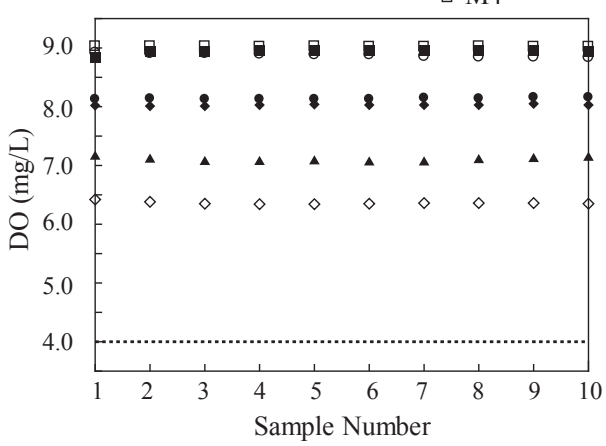

Fig. 5. DO values at the seven confluences of the tributaries and the Cai River.

- M1 • M5

$\mathrm{M} 2 \diamond \mathrm{M} 6$

- M3 $\triangle \mathrm{M} 7$

$\square$ M4

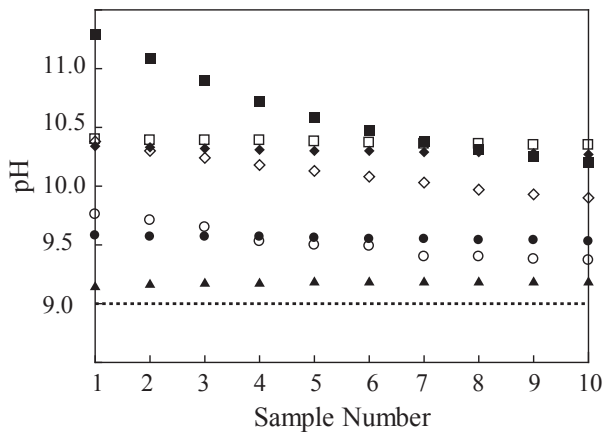

Fig. 4. $\mathrm{pH}$ values at the seven confluences of the Vietnamese Standard of QCVN 08-MT/BTNMT

... Vietnamese Standard of QCVN 08-MT/BTNMT

M1 • M5

$\circ \mathrm{M} 2 \diamond \mathrm{M} 6$

- M3 $\triangle \mathrm{M} 7$

$\square \mathrm{M} 4$

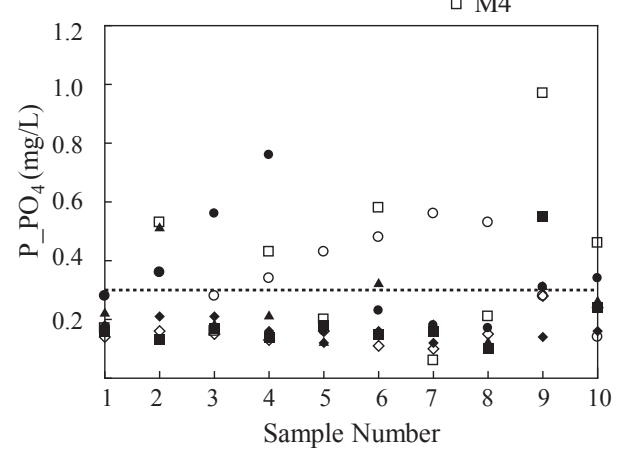

Fig. 8. P-PO4 values at the seven confluences of tributaries and the Cai River. 
The $\mathrm{pH}$ measurements at the confluences along the Cai River are summarized in Tables 4 to 10 as well as in Fig. 4, clearly showing that the $\mathrm{pH}$ indicator of all confluences was outside the allowed limit of QCVN 08-

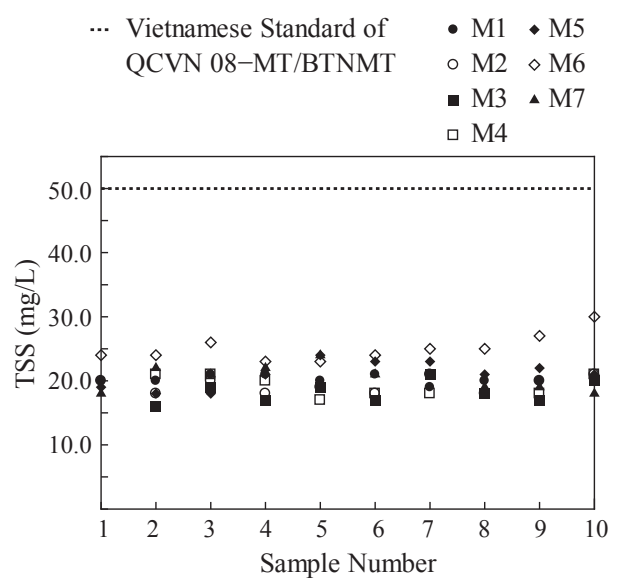

Fig. 9. TSS values at the seven confluences of tributaries and the Cai River.
MT:2015/BTNMT. In particular, the $\mathrm{pH}$ of the water source of the confluence of the Tra Co, Sat, and Cai Rivers (M1) fluctuated at a relatively stable amplitude; the highest was 9.58, and the lowest, 9.53. The $\mathrm{pH}$ at the confluence points M1 (Tra Co, Sat Rivers), M2 (Ong River), and M7 (Lu River) was between 9.0-10.0. The environment was slightly alkaline; however, other confluences had a $\mathrm{pH}>10.0$. Notably, M3, the confluence point of the Cho Mo and Cai Rivers showed a very high $\mathrm{pH}$ of 10.20-11.29. The environments of M3, M4, M5, and M6 were alkaline.

A representation of DO in the confluence area is shown in Fig. 5. and Tables 4 to 10; the water quality in the confluence areas was excellent. The DO was higher than the standard, fluctuated in a narrow range, and was quite stable, proving the accuracy of measurement and analysis. In the rainy season, a huge amount of water would often result in a large flow, so the disturbance and ability to spread was uniform in the area, helping the area to have no organic pollution and to maintain DO at a high and stable level. The confluence points of the

Table 4. Water quality at the confluence of the Tra Co, Sat, and Cai Rivers (M1, see also Table 1), and the permitted standards of the national technical regulation on surface water quality (see also Table 3)

\begin{tabular}{ccccccccc}
\hline No. & Sample & Temp. & $\mathrm{pH}$ & $\begin{array}{c}\mathrm{DO} \\
(\mathrm{mg} / \mathrm{L})\end{array}$ & $\begin{array}{c}\mathrm{BOD}_{5} \\
(\mathrm{mg} / \mathrm{L})\end{array}$ & $\begin{array}{c}\mathrm{COD} \\
(\mathrm{mg} / \mathrm{L})\end{array}$ & $\begin{array}{c}\mathrm{P}_{2} \mathrm{PO}_{4} \\
(\mathrm{mg} / \mathrm{L})\end{array}$ & $\begin{array}{c}\mathrm{TSS} \\
(\mathrm{mg} / \mathrm{L})\end{array}$ \\
\hline 1 & M1-1 & 28.6 & 9.6 & 8.1 & 7.0 & 12.2 & 0.3 & 20.0 \\
2 & M1-2 & 28.6 & 9.6 & 8.1 & 6.0 & 8.1 & 0.4 & 20.0 \\
3 & M1-3 & 28.6 & 9.6 & 8.1 & 6.0 & 9.8 & 0.6 & 21.0 \\
4 & M1-4 & 28.6 & 9.6 & 8.1 & 7.0 & 13.6 & 0.8 & 21.0 \\
5 & M1-5 & 28.6 & 9.6 & 8.1 & 5.0 & 10.1 & 0.2 & 20.0 \\
6 & M1-6 & 28.6 & 9.6 & 8.1 & 5.0 & 10.4 & 0.2 & 21.0 \\
7 & M1-7 & 28.6 & 9.6 & 8.2 & 6.0 & 11.0 & 0.2 & 19.0 \\
8 & M1-8 & 28.7 & 9.5 & 8.1 & 6.0 & 10.9 & 0.2 & 20.0 \\
9 & M1-9 & 28.7 & 9.5 & 8.2 & 7.0 & 10.2 & 0.3 & 20.0 \\
10 & M1-10 & 28.7 & 9.5 & 8.2 & 5.0 & 7.6 & 0.3 & 20.0 \\
& QCVN 08- & & & & & & 0.0 \\
& MT:2015/BTNMT & $5.5-9.0$ & $\geq 4.0$ & 15.0 & 30.0 & 0.3 & 50.0 \\
\hline
\end{tabular}

Table 5. Water quality at the confluence of the Ong and Cai Rivers (M2, see also Table 1), and the permitted standards of the national technical regulation on surface water quality (see also Table 3)

\begin{tabular}{ccccccccc}
\hline No. & Sample & Temp. & $\mathrm{pH}$ & $\begin{array}{c}\mathrm{DO} \\
(\mathrm{mg} / \mathrm{L})\end{array}$ & $\begin{array}{c}\mathrm{BOD}_{5} \\
(\mathrm{mg} / \mathrm{L})\end{array}$ & $\begin{array}{c}\mathrm{COD} \\
(\mathrm{mg} / \mathrm{L})\end{array}$ & $\begin{array}{c}\mathrm{P}_{2} \mathrm{PO}_{4} \\
(\mathrm{mg} / \mathrm{L})\end{array}$ & $\begin{array}{c}\text { TSS } \\
(\mathrm{mg} / \mathrm{L})\end{array}$ \\
\hline 1 & M2-1 & 25.9 & 9.8 & 8.9 & 5.0 & 8.0 & 0.3 & 20.0 \\
2 & M2-2 & 25.9 & 9.7 & 8.9 & 6.0 & 6.2 & 0.4 & 18.0 \\
3 & M2-3 & 25.9 & 9.7 & 8.9 & 5.0 & 5.7 & 0.3 & 20.0 \\
4 & M2-4 & 25.8 & 9.5 & 8.9 & 6.0 & 7.7 & 0.3 & 18.0 \\
5 & M2-5 & 25.8 & 9.5 & 8.9 & 7.0 & 12.2 & 0.4 & 19.0 \\
6 & M2-6 & 25.8 & 9.5 & 8.9 & 6.0 & 12.5 & 0.5 & 18.0 \\
7 & M2-7 & 25.8 & 9.4 & 8.9 & 7.0 & 12.6 & 0.6 & 21.0 \\
8 & M2-8 & 25.7 & 9.4 & 8.9 & 5.0 & 7.0 & 0.5 & 18.0 \\
9 & M2-9 & 25.7 & 9.4 & 8.9 & 5.0 & 8.0 & 0.3 & 20.0 \\
10 & M2-10 & 25.7 & 9.4 & 8.8 & 7.0 & 8.9 & 0.1 & 21.0 \\
\hline
\end{tabular}


Table 6. Water quality at the confluence of the Cho Mo and Cai Rivers (M3, see also Table 1), and the permitted standards of the national technical regulation on surface water quality (see also Table 3)

\begin{tabular}{|c|c|c|c|c|c|c|c|c|}
\hline No. & Sample & Temp. & $\mathrm{pH}$ & $\begin{array}{c}\mathrm{DO} \\
(\mathrm{mg} / \mathrm{L})\end{array}$ & $\begin{array}{c}\mathrm{BOD}_{5} \\
(\mathrm{mg} / \mathrm{L}) \\
\end{array}$ & $\begin{array}{c}\mathrm{COD} \\
(\mathrm{mg} / \mathrm{L})\end{array}$ & $\begin{array}{l}\mathrm{P}_{2} \mathrm{PO}_{4} \\
(\mathrm{mg} / \mathrm{L})\end{array}$ & $\begin{array}{c}\mathrm{TSS} \\
(\mathrm{mg} / \mathrm{L}) \\
\end{array}$ \\
\hline 1 & M3-1 & 28.2 & 11.3 & 8.8 & 6.0 & 12.8 & 0.2 & NA \\
\hline 2 & M3-2 & 28.2 & 11.1 & 8.9 & 8.0 & 13.7 & 0.1 & 16.0 \\
\hline 3 & M3-3 & 28.3 & 10.9 & 8.9 & 8.0 & 9.3 & 0.2 & 19.0 \\
\hline 4 & M3-4 & 28.3 & 10.7 & 9.0 & 12.0 & 11.8 & 0.1 & 17.0 \\
\hline 5 & M3-5 & 28.3 & 10.6 & 9.0 & 14.0 & 12.6 & 0.2 & 19.0 \\
\hline 6 & M3-6 & 28.3 & 10.5 & 9.0 & 11.0 & 12.2 & 0.2 & 17.0 \\
\hline 7 & M3-7 & 28.3 & 10.4 & 9.0 & 10.7 & 12.9 & 0.2 & 21.0 \\
\hline 8 & M3-8 & 28.3 & 10.3 & 9.0 & 7.0 & 15.3 & 0.1 & 18.0 \\
\hline 9 & M3-9 & 28.3 & 10.3 & 9.0 & 7.0 & 16.9 & 0.6 & 17.0 \\
\hline 10 & M3-10 & 28.3 & 10.2 & 8.9 & 5.0 & 14.2 & 0.2 & 20.0 \\
\hline & $\begin{array}{r}\text { QCVN } \\
\text { MT:2015/B }\end{array}$ & & $5.5-9.0$ & $\geq 4.0$ & 15.0 & 30.0 & 0.3 & 50.0 \\
\hline
\end{tabular}

Table 7. Water quality at the confluence of the Than, Dau, and Cai Rivers (M4, see also Table 1), and the permitted standards of the national technical regulation on surface water quality (see also Table 3)

\begin{tabular}{ccccccccc}
\hline No. & Sample & Temp. & $\mathrm{pH}$ & $\begin{array}{c}\mathrm{DO} \\
(\mathrm{mg} / \mathrm{L})\end{array}$ & $\begin{array}{c}\mathrm{BOD}_{5} \\
(\mathrm{mg} / \mathrm{L})\end{array}$ & $\begin{array}{c}\mathrm{COD} \\
(\mathrm{mg} / \mathrm{L})\end{array}$ & $\begin{array}{c}\mathrm{P}_{2} \mathrm{PO}_{4} \\
(\mathrm{mg} / \mathrm{L})\end{array}$ & $\begin{array}{c}\mathrm{TSS} \\
(\mathrm{mg} / \mathrm{L})\end{array}$ \\
\hline 1 & M4-1 & 32.2 & 10.4 & 9.0 & 6.0 & 10.6 & 0.2 & $\mathrm{NA}$ \\
2 & M4-2 & 32.2 & 10.4 & 9.0 & 5.0 & 15.9 & 0.5 & 21.0 \\
3 & M4-3 & 32.2 & 10.4 & 9.0 & 5.0 & 16.8 & 0.2 & 21.0 \\
4 & M4-4 & 32.2 & 10.4 & 9.0 & 5.0 & 10.4 & 0.4 & 20.0 \\
5 & M4-5 & 32.2 & 10.4 & 9.0 & 7.0 & 15.4 & 0.2 & 17.0 \\
6 & M4-6 & 32.3 & 10.4 & 9.0 & 7.0 & 7.8 & 0.6 & 18.0 \\
7 & M4-7 & 32.3 & 10.4 & 9.0 & 5.0 & 16.9 & 0.1 & 18.0 \\
8 & M4-8 & 32.3 & 10.4 & 9.0 & 6.0 & 23.3 & 0.2 & NA \\
9 & M4-9 & 32.3 & 10.4 & 9.0 & 6.0 & 17.5 & 1.0 & 18.0 \\
10 & M4-10 & 32.3 & 10.4 & 9.0 & 5.0 & 14.2 & 0.5 & 21.0 \\
& QCVN 08- & MT:2015/BTNMT & $5.5-9.0$ & $\geq 4.0$ & 15.0 & 30.0 & 0.3 & 50.0 \\
\hline
\end{tabular}

Table 8. Water quality at the confluence of the Ngang and Cai Rivers (M5, see also Table 1), and the permitted standards of the national technical regulation on surface water quality (see also Table 3)

\begin{tabular}{|c|c|c|c|c|c|c|c|c|}
\hline No. & Sample & Temp. & $\mathrm{pH}$ & $\begin{array}{c}\mathrm{DO} \\
(\mathrm{mg} / \mathrm{L})\end{array}$ & $\begin{array}{l}\mathrm{BOD}_{5} \\
(\mathrm{mg} / \mathrm{L})\end{array}$ & $\begin{array}{c}\mathrm{COD} \\
(\mathrm{mg} / \mathrm{L}) \\
\end{array}$ & $\begin{array}{l}\mathrm{P}_{2} \mathrm{PO}_{4} \\
(\mathrm{mg} / \mathrm{L})\end{array}$ & $\begin{array}{c}\mathrm{TSS} \\
(\mathrm{mg} / \mathrm{L}) \\
\end{array}$ \\
\hline 1 & M5-1 & 28.1 & 10.3 & 8.0 & 5.0 & 10.8 & 0.2 & 19.0 \\
\hline 2 & M5-2 & 28.1 & 10.3 & 8.0 & 5.0 & 10.6 & 0.2 & 18.0 \\
\hline 3 & M5-3 & 28.1 & 10.3 & 8.0 & 7.0 & 12.8 & 0.2 & 18.0 \\
\hline 4 & M5-4 & 28.1 & 10.3 & 8.0 & 5.0 & 9.8 & 0.2 & 21.0 \\
\hline 5 & M5-5 & 28.1 & 10.3 & 8.0 & 6.0 & 8.5 & 0.1 & 24.0 \\
\hline 6 & M5-6 & 28.1 & 10.3 & 8.0 & 6.0 & 11.1 & 0.2 & 23.0 \\
\hline 7 & M5-7 & 28.1 & 10.3 & 8.0 & 6.0 & 13.2 & 0.1 & 23.0 \\
\hline 8 & M5-8 & 28.1 & 10.3 & 8.0 & 7.0 & 15.4 & 0.1 & 21.0 \\
\hline 9 & M5-9 & 28.1 & 10.3 & 8.1 & 5.0 & 12.7 & 0.1 & 22.0 \\
\hline 10 & M5-10 & 28.2 & 10.3 & 8.0 & 5.0 & 8.8 & 0.2 & 21.0 \\
\hline \multicolumn{3}{|c|}{$\begin{array}{c}\text { QCVN 08- } \\
\text { MT:2015/BTNMT }\end{array}$} & $5.5-9.0$ & $\geq 4.0$ & 15.0 & 30.0 & 0.3 & 50.0 \\
\hline
\end{tabular}


Table 9. Water quality at the confluence of the Quao and Cai Rivers (M6, see also Table 1), and the permitted standards of the national technical regulation on surface water quality (see also Table 3)

\begin{tabular}{|c|c|c|c|c|c|c|c|c|}
\hline No. & Sample & Temp. & $\mathrm{pH}$ & $\begin{array}{c}\mathrm{DO} \\
(\mathrm{mg} / \mathrm{L})\end{array}$ & $\begin{array}{l}\mathrm{BOD}_{5} \\
(\mathrm{mg} / \mathrm{L})\end{array}$ & $\begin{array}{c}\mathrm{COD} \\
(\mathrm{mg} / \mathrm{L}) \\
\end{array}$ & $\begin{array}{l}\mathrm{P}_{2} \mathrm{PO}_{4} \\
(\mathrm{mg} / \mathrm{L})\end{array}$ & $\begin{array}{c}\mathrm{TSS} \\
(\mathrm{mg} / \mathrm{L}) \\
\end{array}$ \\
\hline 1 & M6-1 & 29.3 & 10.4 & 6.4 & 5.0 & 8.4 & 0.1 & 24.0 \\
\hline 2 & M6-2 & 29.3 & 10.3 & 6.4 & 7.0 & 12.4 & 0.2 & 24.0 \\
\hline 3 & M6-3 & 29.4 & 10.2 & 6.4 & 7.0 & 7.6 & 0.2 & 26.0 \\
\hline 4 & M6-4 & 29.4 & 10.2 & 6.3 & 7.0 & 10.8 & 0.1 & 23.0 \\
\hline 5 & M6-5 & 29.3 & 10.1 & 6.3 & 6.0 & 10.3 & 0.2 & 23.0 \\
\hline 6 & M6-6 & 29.3 & 10.1 & 6.4 & 5.0 & 10.8 & 0.1 & 24.0 \\
\hline 7 & M6-7 & 29.3 & 10.0 & 6.4 & 6.0 & 15.1 & 0.1 & 25.0 \\
\hline 8 & M6-8 & 29.3 & 10.0 & 6.4 & 5.0 & 13.4 & 0.2 & 25.0 \\
\hline 9 & M6-9 & 29.3 & 9.9 & 6.4 & 7.0 & 10.9 & 0.3 & 27.0 \\
\hline 10 & M6-10 & 29.3 & 9.9 & 6.4 & 6.0 & 12.6 & 0.2 & 30.0 \\
\hline \multicolumn{3}{|c|}{$\begin{array}{c}\text { QCVN 08- } \\
\text { MT:2015/BTNMT }\end{array}$} & $5.5-9.0$ & $\geq 4.0$ & 15.0 & 30.0 & 0.3 & 50.0 \\
\hline
\end{tabular}

Table 10. Water quality at the confluence of the Lu and Cai Rivers (M7, see also Table 1), and the permitted standards of the national technical regulation on surface water quality (see also Table 3)

\begin{tabular}{ccccccccc}
\hline No. & Sample & Temp. & $\mathrm{pH}$ & $\begin{array}{c}\mathrm{DO} \\
(\mathrm{mg} / \mathrm{L})\end{array}$ & $\begin{array}{c}\mathrm{BOD}_{5} \\
(\mathrm{mg} / \mathrm{L})\end{array}$ & $\begin{array}{c}\mathrm{COD} \\
(\mathrm{mg} / \mathrm{L})\end{array}$ & $\begin{array}{c}\mathrm{P}_{2} \mathrm{PO}_{4} \\
(\mathrm{mg} / \mathrm{L})\end{array}$ & $\begin{array}{c}\text { TSS } \\
(\mathrm{mg} / \mathrm{L})\end{array}$ \\
\hline 1 & M7-1 & 30.1 & 9.1 & 7.2 & 5.0 & 7.9 & 0.2 & 18.0 \\
2 & M7-2 & 30.1 & 9.2 & 7.1 & 5.0 & 10.0 & 0.5 & 22.0 \\
3 & M7-3 & 30.1 & 9.2 & 7.1 & 7.0 & 7.3 & 0.2 & 21.0 \\
4 & M7-4 & 30.1 & 9.2 & 7.1 & 5.0 & 8.3 & 0.2 & 22.0 \\
5 & M7-5 & 30.1 & 9.2 & 7.1 & 6.0 & 7.7 & 0.1 & 24.0 \\
6 & M7-6 & 30.1 & 9.2 & 7.1 & 6.0 & 15.6 & 0.3 & 21.0 \\
7 & M7-7 & 30.2 & 9.2 & 7.1 & 7.0 & 12.7 & 0.2 & NA \\
8 & M7-8 & 30.2 & 9.2 & 7.1 & 7.0 & 13.0 & 0.1 & 19.0 \\
9 & M7-9 & 30.2 & 9.2 & 7.1 & 6.0 & 15.9 & 0.3 & 19.0 \\
10 & M7-10 & 30.3 & 9.2 & 7.1 & 6.0 & 13.6 & 0.3 & 18.0 \\
\hline
\end{tabular}

Than, Dau, and Cai Rivers (M4), Cho Mo and Cai Rivers (M3), and Ong and Cai Rivers (M2) had the highest DO values of $\sim 9.0 \mathrm{mg} / \mathrm{L}$, as they were located in areas with no dense population; hence, were not polluted by human sources. The value of DO was $\sim 8 \mathrm{mg} / \mathrm{L}$ at the confluence points of the Tra Co, Sat, and Cai Rivers (M1), and at that of the Ngang and Cai Rivers (M5), and was $\sim 7 \mathrm{mg} / \mathrm{L}$ at that of the Lu and Cai Rivers (M7). The lowest value of DO was about $6.5 \mathrm{mg} / \mathrm{L}$ at the confluence of the Quao and Cai Rivers (M6), being located in Phan Rang-Thap Cham City with a dense population and having pollution caused by human activity. In general, the DO results showed that the assimilative capacity of the river was very good.

The $\mathrm{BOD}_{5}$ values at $\mathrm{M} 1$ to $\mathrm{M} 7$ ranged from 5 to $7 \mathrm{mg} / \mathrm{L}$, which was only half of the permissible limit of QCVN 08-MT:2015/BTNMT, as shown in Fig. 6 and Tables 4 to 10 . The fluctuation in $\mathrm{BOD}_{5}$ at the monitoring points was small because the pollutants did not affect the measuring site. Except for the confluence of the Cho Mo and Cai Rivers (M3), BOD 5 was very high (reaching $\sim 14 \mathrm{mg} / \mathrm{L}$ at some points), reaching the standard limitation of QCVN 08-MT:2015/BTNMT. The BOD values indicated mild pollution at the confluences of the Cai River. In particular, the confluence of the Cho Mo and Cai Rivers (M3) was highly polluted; although, the $\mathrm{BOD}_{5}$ was lower than that prescribed by QCVN 08MT:2015/BTNMT.

Through the indicated values, COD was much lower than the standard of QCVN 08-MT:2015/BTNMT and fluctuated in a relatively high amplitude from 5.7$23.3 \mathrm{mg} / \mathrm{L}$ as shown in Fig. 7 and Tables 4 to 10 . The reason for this phenomenon was distribution by depth. The lowest value of COD was in the confluence of the Ong and Cai Rivers (M2), ranging from 5.7-12.6 mg/L. Other confluences had a higher value; the highest was at the confluence of the Than, Dau, and Cai Rivers (M4) measuring $7.8-23.3 \mathrm{mg} / \mathrm{L}$. This may explain why the polluted components were distributed unevenly and depended on the water-depth.

At some monitoring stations, the measured $\mathrm{P}_{-} \mathrm{PO}_{4}$ level exceeded the permitted standard, as shown in Fig. 
8 and Tables 4 to 10 . Especially, the confluence of the Tra Co, Sat, and Cai Rivers (M1), Ong and Cai Rivers (M2), Than, Dau, and Cai Rivers (M4), and one point of the Cho-Mo and Cai Rivers (M3) had an excess $\mathrm{P}_{-} \mathrm{PO}_{4}$ value when compared with the limitation. At the confluence of the Cho Mo and Cai Rivers (M3), P_PO ${ }_{4}$ values fluctuate in a fairly high amplitude from $0.1-0.55 \mathrm{mg} / \mathrm{L}$. It tended to increase gradually downstream, compared with upstream points at the confluence of the Lu and Cai Rivers (M7).

As shown in Fig. 9 and Tables 4 to 10, the TSS was lower than the limitation of QCVN 08-MT:2015/BTNMT.

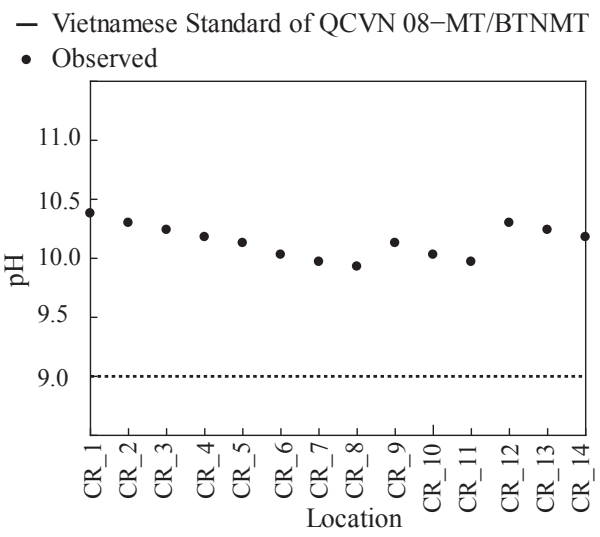

Fig. 10. $\mathrm{pH}$ values of the Cai River.

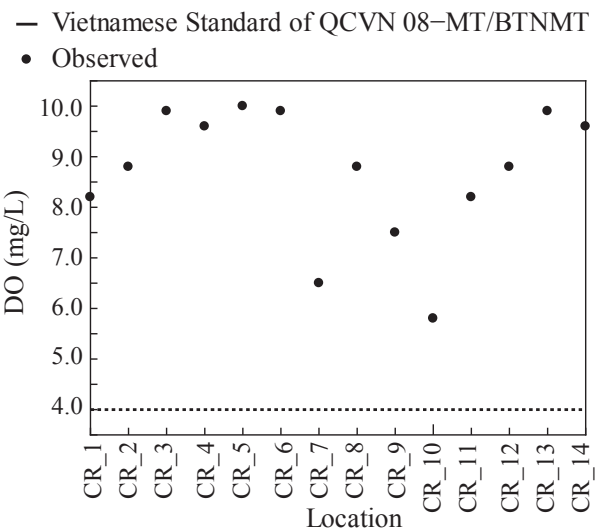

Fig. 11. DO values of the Cai River.

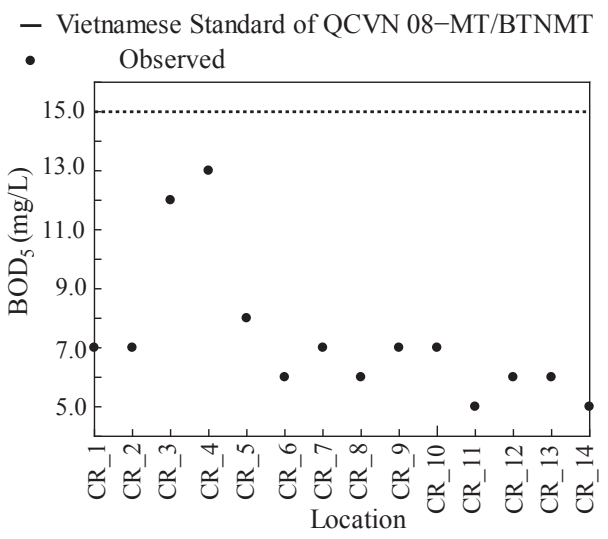

Fig. 12. $B \mathrm{D}_{5}$ values of the Cai River.
The largest TSS concentration was only $20 \mathrm{mg} / \mathrm{L}$, while the limit was $50 \mathrm{mg} / \mathrm{L}$.

\section{Cai River water quality}

Water quality parameters in the Cai River are summarized in Table 11 as well as in Figs. 10 to 15 . This demonstrates that most of the indicators were within permitted limits of QCVN 08-MT:2015/BTNMT and had a broad fluctuation range. The water of the Cai River was slightly alkaline, with a $\mathrm{pH}$ value ranging from 9-10, approximately the measured value of the confluence of the Cai and Lu Rivers. The DO was within the permitted

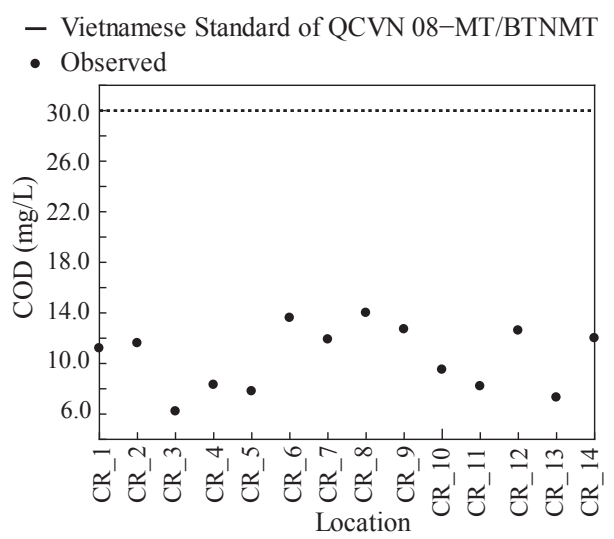

Fig. 13. COD values of the Cai River.

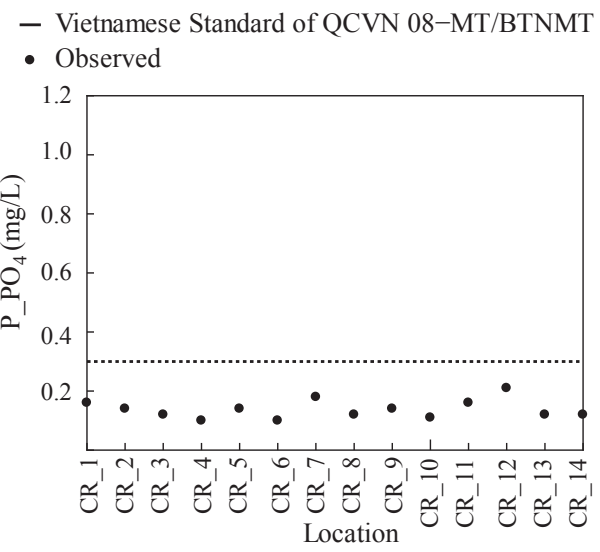

Fig. 14. $\mathrm{P}-\mathrm{PO} 4$ values of the Cai River.

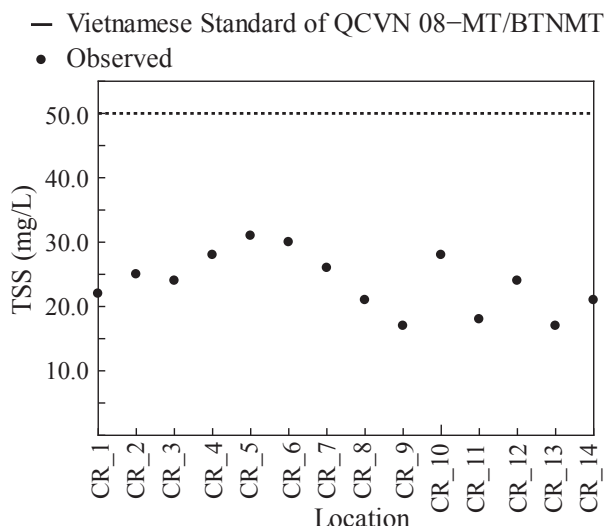

Fig. 15. TSS values of the Cai River. 
limits of QCVN 08-MT:2015/BTNMT with amplitude ranging from $6.09-10.30 \mathrm{mg} / \mathrm{L}$, and $\mathrm{BOD}_{5}$ ranging from $5-13 \mathrm{mg} / \mathrm{L}$, quite similar to the results in other rivers.

Besides, other indicators such as COD, $\mathrm{P} \_P O_{4}$, and TSS had values equal to only half of the allowed value, indicating that the water in the Cai River was not significantly affected by polluting factors.

\section{CONCLUSION}

The prevailing water quality of the Cai River basin was evaluated by investigating the observed water quality in the Cai River and the confluences of its tributaries. In addition, surface water quality was assessed over time and space by determining the trend of water quality and comparing it with the latest national technical regulations on surface water quality of the Ministry of Natural Resources and Environment QCVN 08-MT:2015/BTNMT. For the monitoring points at the Cai River and the confluence of its tributaries, the temperature, $\mathrm{pH}, \mathrm{DO}, \mathrm{COD}$, $\mathrm{P}_{-} \mathrm{PO}_{4}, \mathrm{BOD}_{5}$ and TSS were evaluated.

The results of water quality analysis at the confluence of the Tra Co and Cai Rivers (M1) showed that indicators such as $\mathrm{pH}$ and $\mathrm{P}_{-} \mathrm{PO}_{4}$ were outside the limitation of QCVN 08-MT:2015/BTNMT. The DO in water was higher while the $\mathrm{BOD}_{5}$, COD, and TSS indices were lower than the limitation. The water quality in the confluence area was observed to be particularly good.

At the confluence of the Ong and Cai River (M2), the $\mathrm{DO}, \mathrm{BOD}_{5}, \mathrm{COD}$, and TSS indices were within the permitted limits of QCVN 08-MT:2015/BTNMT. The DO in the water in the confluence area fluctuated within a narrow range and was quite stable. The $\mathrm{BOD}_{5}$ values varied from $5-7 \mathrm{mg} / \mathrm{L}$ and was only half of the permissible limit of QCVN 08-M:2015T/BTNMT. The COD value was much lower than that of the standard. The values of
$\mathrm{BOD}_{5}$ and COD were quite similar, proving that the water in the area had no cell components or biodegradation. Some monitoring stations measured the $\mathrm{P}_{-} \mathrm{PO}_{4}$ level to be in excess of the permitted standard.

The water quality at the confluence of the Cho Mo and Cai Rivers (M3) was mostly within the allowed limits of QCVN 08-MT:2015/BTNMT. The environment was alkaline with a $\mathrm{pH}>10$, but the $\mathrm{pH}$ was less volatile than the confluence point of the Ong and Cai Rivers (M2). The DO was much higher than the standard. The water quality in the confluence area was observed to be acceptable, proving the absence of organic pollution. The $\mathrm{BOD}_{5}$ values ranging from $5-14 \mathrm{mg} / \mathrm{L}$, were within permitted limits of QCVN 08-MT:2015/BTNMT, quite similar to the results at the confluence of the river. $\mathrm{P}_{-}$ $\mathrm{PO}_{4}$ values fluctuated from $0.10-0.55 \mathrm{mg} / \mathrm{L}$. The TSS index was within the allowable limits. The similarity in measurements at the above points demonstrated the objectivity and accuracy of our work, because it accurately reflected the water quality and characteristics at the monitoring points (upstream area). There was minimal socio-economic development activity, sparse population density, the quality of water sources had been unaffected, and the impact of agricultural and industrial activities was minimal.

At the confluence of the Than and Cai Rivers (M4), half of the indicators were within permitted limits of QCVN 08-MT:2015/BTNMT. The pH fluctuated at 10, indicating a slightly alkaline environment. The DO was higher than the standard, fluctuating within a narrow, stable range. Similar to the confluence of the Cho Mo and Cai Rivers (M3), the $\mathrm{BOD}_{5}$, COD, and TSS indicators were still within allowed limits. In particular, the largest value of TSS was only $21 \mathrm{mg} / \mathrm{L}$, while the limit was $50 \mathrm{mg} / \mathrm{L}$. $\mathrm{P}_{-} \mathrm{PO}_{4}$ levels were still much higher than that in QCVN 08-MT:2015/BTNMT.

Table 11. Water quality of the Cai River and the permitted standards of the national technical regulation on surface water quality (see also Table 3)

\begin{tabular}{ccccccccc}
\hline No. & Location & Temp. & $\mathrm{pH}$ & $\begin{array}{c}\mathrm{DO} \\
(\mathrm{mg} / \mathrm{L})\end{array}$ & $\begin{array}{c}\mathrm{BOD}_{5} \\
(\mathrm{mg} / \mathrm{L})\end{array}$ & $\begin{array}{c}\mathrm{COD} \\
(\mathrm{mg} / \mathrm{L})\end{array}$ & $\begin{array}{c}\mathrm{P}_{2} \mathrm{PO}_{4} \\
(\mathrm{mg} / \mathrm{L})\end{array}$ & $\begin{array}{c}\text { TSS } \\
(\mathrm{mg} / \mathrm{L})\end{array}$ \\
\hline 1 & CR_1 & 28.8 & 10.0 & 8.2 & 7.0 & 11.2 & 0.2 & 22.0 \\
2 & CR_2 & 29.2 & 9.3 & 8.8 & 7.0 & 11.6 & 0.1 & 25.0 \\
3 & CR_3 & 30.9 & 9.3 & 9.9 & 12.0 & 6.2 & 0.1 & 24.0 \\
4 & CR_4 & 30.2 & 9.7 & 9.6 & 13.0 & 8.3 & 0.1 & 28.0 \\
5 & CR_5 & 30.7 & 10.0 & 10.0 & 8.0 & 7.8 & 0.1 & 31.0 \\
6 & CR_6 & 32.0 & 10.0 & 9.9 & 6.0 & 13.6 & 0.1 & 30.0 \\
7 & CR_7 & 30.7 & 9.0 & 6.5 & 8.0 & 11.9 & 0.2 & 30.0 \\
8 & CR_8 & 30.5 & 9.3 & 8.8 & 6.0 & 14.0 & 0.1 & 21.0 \\
9 & CR_9 & 30.1 & 9.2 & 7.5 & 6.0 & 12.7 & 0.1 & 21.0 \\
10 & CR_10 & 29.1 & 8.8 & 5.8 & 5.0 & 9.5 & 0.1 & 27.0 \\
11 & CR_11 & 28.8 & 10.0 & 8.2 & 7.0 & 11.2 & 0.2 & 22.0 \\
12 & CR_12 & 29.2 & 9.3 & 8.8 & 7.0 & 11.6 & 0.1 & 25.0 \\
13 & CR_13 & 30.9 & 9.3 & 9.9 & 12.0 & 6.2 & 0.1 & 24.0 \\
14 & CR_14 & 30.2 & 9.7 & 9.6 & 13.0 & 8.3 & 0.1 & 28.0
\end{tabular}


At the confluence of the Ngang and Cai Rivers (M5), most of the indicators were within allowable limits of QCVN 08-MT:2015/BTNMT, including DO, BOD 5 , COD, TSS, and $\mathrm{P}_{-} \mathrm{PO}_{4}$. The values fluctuated within a narrow range and were quite stable. The $\mathrm{pH}$ values at the monitoring points did not differ significantly; both were above 10, indicating slightly alkaline water. The $\mathrm{P}_{-} \mathrm{PO}_{4}$ value was higher than the permitted standard, reflecting the prevailing situation, characteristics, and socio-economic development of the Ngang River, which has a stable flow. A few people lived in this area.

At the confluence of the Quao and Cai Rivers (M6), the water quality was quite similar to that at the confluence of the Ngang and Cai Rivers (M5). The measured values of $\mathrm{DO}, \mathrm{BOD}_{5}, \mathrm{COD}$, TSS, and $\mathrm{P}_{-} \mathrm{PO}_{4}$ were within permitted limits of QCVN 08-MT:2015/BTNMT. The water in the confluence area was slightly alkaline. The DO, being at the permissible level, did not fluctuate much; however, it decreased significantly compared to the confluence of the Ngang and other rivers. It could be concluded that the water quality of this confluence was poor, being located in a city with dense population. The values of COD ranged from 7.6-15.1 mg/L, much smaller than the allowed maximum of $30 \mathrm{mg} / \mathrm{L}$.

The results of water quality analysis at the confluence of the Lu and Cai Rivers (M7), suggested an increase in organic as well as inorganic pollutants. The $\mathrm{pH}$ of the water source fluctuated within a narrow range from 9.14-9.18, which was highly stable. The measured values of $\mathrm{BOD}_{5}, \mathrm{COD}$, and TSS were similar to the confluence of the Quao and Cai Rivers (M6), and within permitted levels. $\mathrm{P}_{-} \mathrm{PO}_{4}$ levels tended to gradually increase downstream, compared with the upstream points. Three monitoring points recorded values in excess of the allowed levels of QCVN 08-MT:2015/BTNMT. The average value of DO had decreased compared to the confluence of the Ngang and Cai Rivers (M5), although still higher than the standard, but it also partly reflected the degradation in water quality of the confluence with the Cai River in the downstream area.

Most of the indicators of water quality in the Cai River are within the permitted limits of QCVN 08MT:2015/BTNMT. The water of the Cai River is slightly alkaline. This shows that the water in the Cai River is not significantly affected by polluting factors.

\section{AUTHOR CONTRIBUTIONS}

T. A. NGOC and V. T. H. THU designed the study and conducted field observations. V. L. D. THAI, D. V. DAO, V. H. SON, and P. T. H. SON contributed to the field observations. T. A. NGOC and V. T. H. THU wrote the draft. K. HIRAMATSU revised the manuscript and assisted in its preparation. All authors approved the final version of the manuscript and agreed to be accountable for all aspects, ensuring that issues related to the accuracy or integrity of any part of the work are appropriately investigated and resolved.

\section{REFERENCES}

Department of Natural Resources and Environment of Ninh Thuan Province (DONRE) 2018 Quarter IV - Report on surface water quality in Ninh Thuan Province, pp. 18-42. (in Vietnamese)

Meybeck, M., E. Kuusisto, A. Mäkelä and E. Mälkki 1996 Chapter 2 Water Quality. In "Water Quality Monitoring - A Practical Guide to the Design and Implementation of Freshwater Quality Studies and Monitoring Programmes", UNEP/WHO, pp. 18-46.

Ministry of Natural Resources and Environment (MONRE) 2008 National technical regulation on surface water quality QCVN 08MT:2015/BTNMT, pp. 5-12. (in Vietnamese)

Ministry of Natural Resources and Environment (MONRE) 2009 Circular 02/2009/TT-BTNMT: Regulation on assessment of water sources' ability to receive wastewater, pp. 1-12. (in Vietnamese)

Ministry of Natural Resources and Environment (MONRE) 2011 Circular 29/2011/TT-BTNMT: Regulation on technical process of environmental monitoring of continental surface water, pp. 50-57. (in Vietnamese)

Ministry of Natural Resources and Environment (MONRE) 20015 National technical regulation on surface water quality QCVN 08MT:2015/BTNMT, pp. 3-5. (in Vietnamese)

Pham, A. D, N. T. M. Linh, L. P. Quoi and L. P. Nga 2011 Comparing pollution score and water quality index in assessment of water quality downstream of Dong Nai river system. Journal of Science and Technology, 49(5C), pp. 126-135. (in Vietnamese)

Ton, T. L. 2007 Developing quality indicators to assess and manage water quality in Dong Nai river system. Proceedings of $10^{\text {th }}$ Scientific Conference, Natural Resources and Environment University Press, Ho Chi Minh (Vietnam), pp. 262-268. (in Vietnamese) 